\title{
Democracy, Authoritarianism, and COVID-19 Pandemic Management: The Case of SARS-CoV-2 Testing
}

\author{
(Working paper) \\ German Petersen ${ }^{1}$ \\ ITESO
}

July 15,2020

\begin{abstract}
A strand of political economy literature expects democratic governments to be more effective than their authoritarian peers in the management of catastrophic situations (famines, natural disasters, pandemics, etc.) due to the responsiveness that stems from accountability. The ongoing COVID-19 pandemic offers an interesting setting to test this expectation, in particular to explore whether democracies are more preventive and therefore massify testing. Towards evaluating governmental response, indicators such as number of cases, contagion rates, and deaths are not useful because their variations exceed what governments are able to do; in contrast, SARS-CoV-2 testing is in the hands of governments. Analyzing data from 85 countries, the more democratic a country is, not necessarily the more tests it runs. The relationship is rather curvilinear, best described by a U, with low and high levels of democracy associated with the massification of testing, and medium levels associated with low testing. Besides testing democracies and non-testing authoritarianisms, there are testing authoritarianisms basically rentier states - and non-testing democracies; anocracies tend to be non-testing across the board. The variance in testing seems to be also partially explained by GDP per capita and government effectiveness, but surprisingly unrelated to the length of the pandemic in a country.
\end{abstract}

\footnotetext{
${ }^{1}$ Associate Professor. Departamento de Estudios Sociopolíticos y Jurídicos. Instituto Tecnológico y de Estudios Superiores de Occidente (ITESO). Periférico Sur Manuel Gómez Morin 8585, Col. Santa María Tequepexpan, San Pedro Tlaquepaque, Jalisco, C.P. 45604. E-mail address: gpetersen@iteso.mx. Phone number: +52333693434. I appreciate the assistance of Alejandro Strozzi.
} 


\section{$1 \quad$ Introduction}

Democracies are believed to react better to catastrophes than authoritarianisms. The classical political economy work on this subject focuses on famines as a catastrophic situation (Drèze \& Sen, 1989, 1990; Sen, 1982, 1999). According to this line of inquiry, since in democracies executives are subject to accountability links with the citizenry — at least elections - and with other institutions (legislative, judicial, international, etc.), they are induced to increase their responsiveness and improve their performance. In contrast, authoritarian executives do not have clear institutionalized channels to receive pressure from the public, which allows them to ignore demands for prevention strategies and therefore are outperformed by democracies.

The ongoing COVID-19 pandemic offers an interesting setting to test such proposition. Are democratic governments indeed managing the epidemic better than authoritarianisms? In answering this question, the first challenge is to operationalize effectiveness in the management of the pandemic. The problem is that, while the public sector can have a large impact in the containment of a pandemic, the scope of governmental action is limited. Thinking in the COVID-19 pandemic in particular, indicators such as the number of people infected, the rate of contagion, the death toll, etc. depend on several factors that certainly include governments, but that are not limited to them, since the behavior of society, the health pre existing conditions of the population, public health provision, poverty and inequality that impede social isolation, etc. also have an effect.

However, there is a particular aspect of the pandemic management that does depend mainly or entirely on governments: testing for SARS-CoV-2, the virus that causes this coronavirus dis-

ease. In particular, what interested here is Polymerase Chain Reaction (PCR) testing, which has been acknowledged as the most accurate type of test, while other types of tests are highly contested — such as the antigen or so-called rapid tests (Hahn et al., 2020; John Hopkins University, 2020; Whitman et al., 2020; Woloshin et al., 2020). Adopting a comparative approach, in basically all of the countries the government is the only institution allowed to test or run the majority 
of the tests, and also regulates the testing campaign. Additionally, as will be argued further on, the number of tests per 1,000 people are much more comparable from country to country than the number of people infected since methodologies to count cases vary widely - ergo, there is no possibility of comparison either of contagion rates or the mortality rates, since the number of cases is factored into this data. Thus, testing offers a fine indicator to assess the governmental response to COVID-19 in democratic and authoritarian contexts.

The expectation of the literature is the more democratic a country is, the more it will prioritize testing. Analyzing evidence from 85 countries, this does not hold totally true. In line with the expectation of the literature, there are indeed democracies that test massively - testing democracies, such as Iceland, Luxembourg, Denmark, Portugal, and Lithuania- and authoritarianisms that have only implemented extremely limited testing campaigns —non-testing authoritarianisms, like Cuba, Bangladesh, Vietnam, Iran, and Thailand. Nevertheless, there are also three categories of countries that do not fit the theoretical expectation. First, there are non-testing democracies — Costa Rica, Uruguay, France, Japan and Greece-, which against the expectation for democracies did not massify testing. Second, there is a very limited amount but nonetheless existent of testing authoritarianisms - Bahrain, Qatar, Russia, and Belarus-, which bring into question the assumption that non-accountable regimes are not prone to a cautious management of a pandemic. Lastly, among anocracies, there are mostly non-testing cases - Hungary, Paraguay, El Salvador, Nepal and Rumania-, which in fact suggests that the incentives to fail in testing are not proper of democracies or authoritarianisms, but rather of the absence of both.

As can be foreseen though, the regime type is not the only factor that has an effect on the scale of testing. There are two structural factors that have a high correlation with testing: GDP per capita and governmental effectiveness. On the one hand, developing countries tend to test much less than developed countries. On the other hand, countries with more effective public sectors tend to test more than their institutionally-weak peers. Interestingly, the rhythm of the pandemic does not seem to be that explanatory of the response a country adopts. Initially, the expectation was that countries that began first with their national epidemics would have tested more until this point than those that began afterwards. Results show, nonetheless, that that is 
not the case. In fact, there seems to be no correlation between the date the first case was reported in a country and the number of tests per 1,000 performed.

The work relies on several sources: Our World in Data, Varieties of Democracy (V-Dem), Maddison Project Database, Worldwide Governance Indicators, the European Center for Disease Prevention and Control, and national governments' reports. From Our World in Data, the paper takes the dependent variable, this is, the number of tests ran per 1,000 people. Our World in Data considers only PCR tests, which — as said - are the most effective type of tests. In turn, Our World in Data updates this indicator based on the reports released by each country. Some countries report not only the number of PCR tests applied, but also the number of people tested with those tests, which is necessarily larger because some people have been tested more than once. When present, the paper reports both pieces of information. The current version of this paper uses data updated until May 28. From V-Dem, the work takes the independent variable of interest, level of democracy, resorting to the Liberal Democracy Index and the Electoral Democracy Index. These V-Dem indexes are based on perception surveys applied to country experts.

As mentioned above, besides the political factor regime type, there are other economic, institutional, and pandemic factors that potentially have an effect on the massification of testing. These factors are explored as alternative hypotheses. Data for GDP per capita and governmental effectiveness are taken, respectively, from the Maddison Project Database and the Worldwide Governance Indicators. The date of the first coronavirus case in each country comes from Our World in Data, which in turn uses the information from the European Center for Disease Prevention and Control.

The work has four sections, plus the Conclusion. First, I review briefly the literature on democracy and catastrophe management. Second, I elaborate on the main traits of the COVID19 pandemic, the relevance and particularities of SARS-CoV-2 testing, and why testing works as an indicator to assess the response democratic and authoritarian governments have had to the COVID-19 pandemic. Third, I introduce the relationship between level of democracy and number of tests and display the five categories that stem from this relationship: the expected testing 
democracies and non-testing authoritarianism, and the unexpected non-testing democracies, testing authoritarianism, and non-testing anocracies. In this same section, I elaborate on the countries that can be classified in each of these categories. Fourth, I test the mentioned alternative hypotheses - GDP per capita, government effectiveness, and day of detection of the first COVID19 case. In the Conclusion I reflect broadly on the implications of this findings for our understanding of the relationship between regime type, structural factors, and pandemic management, particularly with regards to prevention strategies.

\section{Democracy and Catastrophe Management}

In a book that has become a classic - Poverty and Faminess-, Sen (1982) explained famines from a very different standpoint than the existent one. Against the usual explanation related with the availability of food, Sen argued that famines were more related with economic entitlements and political accountability. On the latter, political point, the author asserted that democracies were better suited than authoritarianisms to deal with the threat of famines, given the accountability that elections implied and the rest of institutional accountability mechanisms legislative, judicial, international. In his line of reasoning, accountability makes democracies more responsive to the demands of citizens for a more equal distribution of food, which prevented famines from happening. To empirically substantiate the argument, Sen analyzed several famines, among them the 1943 Bengal Famine, the 1973 and 1974 Ethiopia famines, and the 1974 Bangladesh famine.

Drèze \& Sen $(1989,1990)$ continued exploring famines, focusing on political and economic reform as means to assure food security, particularly for the most disadvantaged. Later on, in his well-known Development as Freedom, Sen summarized his years of research on famine in a bold phrase that has become famous: "No famine has ever taken place in the history of the world in a functioning democracy" (Sen, 1999: 16). Since these pieces of research, several authors have corroborated Sen's findings (Burchi, 2011; Rubin, 2009, 2011). 
A broader line of inquiry has opened on political factors and the management of catastrophes in general, including famines (de Waal, 1989, 1990; Watts, 2013), but also other catastrophes (earthquakes, floods, hurricanes, etc.). One of the main takeaways of this literature is that the so-called natural disasters are not that "natural", but a consequence of vulnerabilities produced by economic, social, and political arrangements (see Blaikie et al., 2014). After analyzing the politics of states responses to natural disasters in 150 countries during a 14-year period 1995-2009-, Lin (2015) concluded that having a democratic regime and a strong state, and more so the combination of both factors, increases the likelihood of responding effectively to a natural disaster, particularly visible in a reduction of the mortality rate. Of course, responses adopted by democracies vary from context to context depending on institutional and structural features (Platt, 2012), but in general democracies are believed to respond better to this kind of situations.

While there is plenty of research on democracy, authoritarianisms, famines and natural disasters, there are scarce insights on political regimes and pandemics, an important them in the current global context. Some authors have drawn upon the extant literature to attempt to understand the politics involved in the management of the current COVID-19 pandemic. Sen himself, in a recent piece for the Financial Times, evocated his work on famines to elucidate possibilities in face of the COVID-19 pandemic, arguing "politics is important here, including the relation between rulers and governed".

The quantitative evidence on the performance of democracies in face of the pandemic, however, is not conclusive. Kavanagh \& Singh (2020) have explored the impact of democracy, authoritarianism and state capacity on the management of the pandemic, but done so based on examples, not systematic evidence. Cepaluni et al. (2020) argue that democracy was related with more deaths per capita in the first stage of the pandemic and associate this association to ineffective policy responses. Cheibub et al. (2020) argue that democracies tended to have a slower response to the pandemic than authoritarianisms, apparently due to their refusal to limit civil liberties, which could explain the greater excess death identified by Cepaluni et al. Frey et al. (2020) distinguish between the measures imposed and actual reduction of mobility and conclude 
that, although authoritarianisms imposed more stringent measures, the reduction of mobility actually happened more in democracies and in countries with a collectivist culture -as opposed to an individualist culture. Although the COVID-19 pandemic is ongoing, and therefore trends might change in the future, this work seeks to explore whether or not the optimism of the literature on democracies and catastrophes expressed in a higher propensity to massify SARSCoV-2 testing.

\section{COVID-19 Pandemic and SARS-CoV-2 Testing}

In December 2019, the Wuhan Municipal Health Commission acknowledged the existence of 27 cases of pneumonia of an unidentified viral, flu-like origin. The majority of the cases were workers of a local food market. A few days later, the Chinese government acknowledged that the disease causing the pneumonia and the virus originating the disease did not appear in medical records (Zuo, M. et al., 2020; Reuters, 2020). On February 11, the World Health Organization (WHO) labeled the disease coronavirus disease 19 (COVID-19) and the International Committee on Taxonomy of Viruses (ICTV) named the virus acute respiratory syndrome coronavirus 2 (SARSCoV-2) (WHO, 2020e). The most common symptoms included headache, loss of smell, nasal obstruction, cough, and asthenia (fatigue). However, myalgia (muscle pain), rhinorrhea (abundant mucus fluid in nose), gustatory dysfunction, sore throat, and fever may also occur (Lechien et al., 2020; International Severe Acute Respiratory and Emerging Infection Consortium, 2020).

During January 2020, the World Health Organization (WHO) held several meetings to analyze the disease and to evaluate the threat it represented for global health. On January 30, the WHO Director General, Tedros Adhanom, announced that COVID-19 was elevated to the rank of Public Health Emergency of International Concern (PHEIC), due to its severity, transmissibility — not only airborne from person-to-person but also through surfaces - , and the high proportion of asymptomatic carriers who could nevertheless propagate the disease (WHO, 2020g, 2020h). The sum of these elements pointed out to a possible exponential growth with a pandemic potential. Until the last day of January, 9,776 people had been infected —out of whom 213 had 
died-, the immense majority of cases inside China, but 98 of them abroad, distributed in 18 countries (New York Times, 2020). During February, the epidemic expanded especially in China, but also in South Korea, Italy, and Iran. By the end of the month, China reported 79,355 cases and 2,837 deaths, and South Korea, Italy, and Iran, totalized together 4,207 cases and 71 deaths (New York Times, 2020; ECDC, 2020).

On March 11, the WHO stated the coronavirus outbreak had become a pandemic (Adhanom, 2020a). During this month, the number of identified COVID-19 patients worldwide grew seven times, reaching 700,000, and in the beginning of April the number broke the million threshold. The epicenter of the pandemic moved from China to Europe - especially Italy and Spain (WHO, 2020b). However, since an important number of cases began to be detected in the U.S. By the end of April, Europe reached 1.3 million cases and 133,254 deaths, followed closely by the U.S. with around a million cases and 60,966 deaths. In May, Europe managed to implement strict measures — headed by lockdowns - that took the epidemic to a peak and brought it down consistently; in contrast, the U.S. only managed to decrease the rate of growth and bring about minor, temporal descends (WHO, 2020; ECDC, 2020).

In May and particularly June, the pandemic took Latin American as a new epicenter particularly Brazil and Peru. In the beginning of May, the region accounted 176,740 cases and 8,699 deaths; on June 30, the outlook was radically different: the number of detected cases had reached 844,992 - growing almost five times from the beginning of May - and the number of COVID-related deaths touched 39,324 — four times more than in early May (ECDC, 2020).

The massification of SARS-CoV-2 testing is one of the most recommended strategies to contain and eventually mitigate the expansion of COVID-19. WHO Director General Adhanom has been quite vocal about the point, arguing "the most effective way to prevent infections and save lives is breaking the chains of transmission. And to do that, you must test and isolate." (Adhanom, 2020c). The WHO as an institution has also advocated for this approach in its guidelines to combat the virus (Adhanom, 2020b, 2020d; WHO, 2020a, 2020c, 2020d, 2020f, 2020i). Despite the short time elapsed since the outburst of the COVID-19 pandemic, there is already plenty of academic work on the subject, pointing out the importance of testing, and particularly 
PCR testing, with the purpose of confining infected people - be them symptomatic or asymptomatic - and tracing their possible chains of contagion to identify and confine other infected people (Arons et al., 2020; Gandhi et al., 2020; Hellewell et al., 2020; Morawska \& Cao, 2020; Kucharski et al., 2020; Walker et al, 2020). Prestigious research centers such as the Centers for Disease Control and Prevention (CDC) and the National Health Insitutes (NIH) have also pointed in the same direction (CDC, 2020a, 2020b, 2020c; Collins, 2020; NIH, 2020).

Despite the sound scientific rationale to massify testing, there is one big hurdle: the cost of PCR tests. The price of a single test is of approximately $\$ 150$ USD, varying importantly from country to country, with the cheapest around $\$ 60$ USD and the most expensive around $\$ 400$ USD (Centers for Medicare \& Medicaid Services, 2020; Lee, D. \& Lee, J., 2020; Ministry of Health of Singapore, 2020; Ministry of Health of Iceland, 2020). Of course, this unitary price should be multiplied by hundreds of thousands or even millions in some cases, with the resources being necessarily spent in a short period of time and without having foreseen the item in the budget.

From a methodological standpoint however, SARS-CoV-2 testing offers an interesting tool to assess the governmental response to the pandemic for at least three reasons. First, as argued, PCR testing is considered crucial to successfully face the COVID-19 pandemic by institutions such as the WHO, CDC, and the NIH, and multiple serious pieces of academic research. Hence, governments have in hand sound evidence that testing should be done. Nevertheless, the public sector faces the obstacle of the cost of a testing campaign, which creates financial and political resistances to its launching that only governments able and committed to allocating these sums of money to testing end up overcoming.

Second, testing as a pandemic management strategy is mainly if not exclusively in the hands of governments. Therefore, from a research perspective, governments can be held accountable for massifying or failing to massify testing. As argued above, other metrics of the pandemic response such as the number of people infected or the people who die of acute COVID-19 depend on factors such as patterns of social behavior, health pre existing conditions of the population, public health provision system, etc. in which not only the governments participates but also the private 
sector and society at large. In contrast, testing is at the very least a government-led strategy in the most various contexts.

Third, the number of tests per 1,000 people is comparable from one country to another. The only difference there might be is that some countries report, besides the number of tests, the number of people tested, since some people have been tested two or even more times (in such cases, the paper reports the two observations). With this caveat made, the number of tests are comparable from country to country. In contrast, other possible metrics regarding the pandemic are not strictly comparable, such as the number of people infected, given that methodologies to count cases vary widely, which in turn also affect the estimation of the contagion and mortality rates. The fact that the disease is in many cases asymptomatic or that presents with mild symptoms also jeopardizes the credibility of the figures on the number of cases.

With these precisions of the COVID-19 pandemic and the SARS-CoV-2 testing established, the following section looks into the relationship between democratic, anocratic, and autocratic regimes and the massification of testing as a widely prescribed response to manage the current pandemic.

\section{Democracies, Authoritarianisms and SARS-CoV-2 Test- ing}

The classical and contemporary political economy literature expects democracies to be more effective in the management of catastrophes - pandemics included - than authoritarianisms. When evaluating the management of the COVID-19 pandemic through the massification of tests - which is a strategy than relies mainly in the hands of governments, be them democratic or not-, this is not quite the case. As can be seen in Figure 1, the relationship between level of democracy — measured with V-Dem's Liberal Democracy Index — and PCR testing — measured with tests per 1,000 people, according to the country reports compiled by Our World in Datais curvilinear, not linear, as the literature would expect (i.e., more democracy, more testing). This is to say, the association is better represented graphically with a $U$ than with slash. On 
average, low scores in the Liberal Democracy Index coincide with high testing in a similar proportion — slightly less - to high scores. In contrast, the regimes that orbit the middle of the Index tend to almost systematically run a low number of tests.

In more substantive terms, under conditions that will be explored below, both authoritarianisms and democracies may produce incentives for governments to massify testing. In contrast, in absence of both authoritarianism and democracy, this is, in the countries that are in the middle of the Index, these incentives are not produced and testing is not massified. The Appendix shows the same relationship but using the Electoral Democracy Index to approximate democracy instead of the Liberal Democracy Index. As can be seen, the curvilinear relationship holds almost identical.

For purposes of this paper, testing governments - be them democratic or authoritarian are understood as those that apply 40 PCR tests or more per 1,000 people, and non-testing governments are those that apply less than 20. With regards to regime type, authoritarian regimes score less than .3 in the Liberal Democracy Index and democratic regimes score more than .7; the regimes in the middle are considered anocracies.

The U-shape relationship between democracy and testing allows to divide the 85 countries into five different categories, taking into consideration two criteria, level of testing - measured through PCR testing per 1,000 people - and regime type - measured through the Liberal Democracy Index. First, testing authoritarianisms — rare, but existent-, with low levels of liberal democracy and high levels of testing, which are all of them rentier states - mainly oil-producing countries-, such as Bahrain, Qatar, and Russia. In rentier states, the public sector has abundant resources available for testing - through a state company or taxes - and strong incentives to maintain social and political stability through the prevention of a disastrous epidemic. Second, testing democracies, with high levels of democracy and high levels of testing, which comply with the expectation of the literature that democracy stimulates accountability and governmental responsiveness - Iceland, Luxembourg, and Denmark.

Third, non-testing authoritarianisms, with low levels of democracy and low levels of testing, which also comply with the expectation of the literature but as the reverse side of the coin, this 
is, countries in which the authoritarian features of the regime produce unaccountable, non-responsive governments - Cuba, Bangladesh, and Vietnam. Fourth, non-testing anocracies, in which the regime is neither fully democratic nor fully authoritarian, and which unlike democracies and authoritarianisms almost systematically show low levels of testing - Hungary, Paraguay, El Salvador. Lastly, non-testing democracies, with high levels of democracy and strangely low levels of testing from the standpoint of the extant literature - Costa Rica, Uruguay, and France.

Figure 1

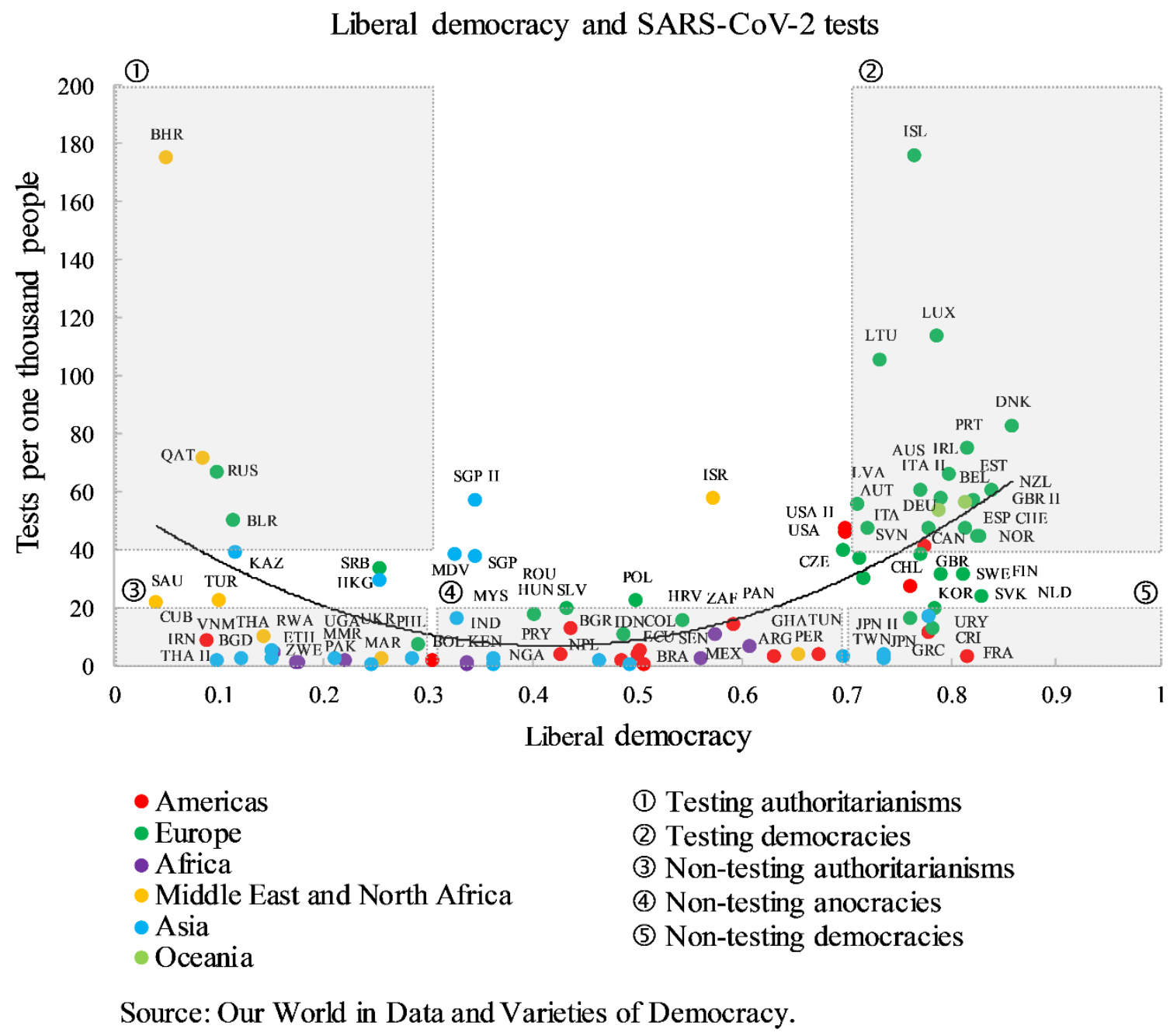

The following sections elaborate on each of these five categories, reflecting on the possible mechanisms that could be connecting regime type with testing and, more broadly, with prevention and pandemic management overall. 


\subsection{Testing Authoritarianisms}

Testing authoritarianisms, authoritarian regimes and high testing, run against the general expectation of the literature. However, only four countries with an authoritarian regime out of 18 authoritarianisms have been able to massify testing — Bahrain, Belarus, Qatar, and Russia(Table 1). In contrast, 19 democracies have been able to do the same. This low number suggests that, although authoritarianisms can become testing in face of a pandemic like the ongoing one, this is rare. In this sense, the literature tends to exaggerate the inability of authoritarianisms to manage pandemics, but is right in pointing out to the fact that there is a limited affinity between this kind of political regimes and governmental effectiveness under catastrophes.

Beyond the mere number, the four countries share the commonality of having, besides authoritarian regimes, rentier states. Rentier states are characterized by being located in countries with an important availability of natural resources from which they ca derive massive rents be them through state companies, be them to taxes on private companies. For years, the literature has shown that rentier states tend to have authoritarian regimes, since governments can fund themselves through their natural endowment, not taxes, precluding democratic accountability, in what has been labeled the "resource curse" (Ross, 1999, 2013, 2015). In particular, Bahrain, Belarus, Qatar, and Russia produce and export hydrocarbons massively, and more specifically oil, which in fact has been seen as the most usual driver of the "curse".

The connections between rentier states and effective pandemic management seems to be driven by economic and political variables. On the one hand, rentier states do have plenty of "easy" resources available, more so in an authoritarian context, which enables the implementation of an ambitious PCR testing strategy, which is particularly expensive. On the other hand, in order to keep the natural resources exploitation process going, on which these regimes depend, political and social stability comes a necessity, and could be jeopardized by COVID-19. In this sense, the massification of testing seems to be not only economically feasible for these governments, but also politically desirable. 
Table 1

Testing authoritarianisms

Country

Bahrain

Belarus

Qatar

Russia

\subsection{Testing Democracies}

Testing democracies, democratic regimes with massive testing, are in line with the expectations of the literature, according to which democracies are better suited than authoritarianism to face catastrophic situations. There are almost five times more testing democracies than testing authoritarianisms - 19 vs. 4-, which suggests a much stronger affinity between democracy and prevention of the effects of COVID-19 as opposed to authoritarianism. From the 31 democratic countries considered in the sample, 19 have been testing. These countries are characterized by the fact that democratic accountability induces governmental responsiveness in face of the catastrophe, pushing up the number of SARS-CoV-2 tests (Table 2).

The testing democracies set is composed basically by European countries — and mainly West European- plus Australia, Canada, and New Zealand. Among the European nations, the ones that have massified testing the most are Iceland, Luxemburg, Lithuania, Denmark, and Portugal, which does not show a particular clustering inside the continent. As can be noticed, these are all developed countries and therefore the effect might be driven, besides by political factors, by the economic factor level of development, which will be analyzed in the following section, Alternative Hypotheses. 
Table 2

Testing democracies

Country

Australia

Austria

Belgium

Canada

Switzerland

Germany

Denmark

Spain

Estonia

United Kingdom

Ireland

Iceland

Italy

Lithuania

Luxembourg

Latvia

Norway

New Zealand

Portugal

\subsection{Non-Testing Authoritarianisms}

Non-testing authoritarianisms, authoritarian regimes that have not massified testing, are in line with the expectation of the literature according to which non-accountable, strong-handed regimes are not effective when dealing with pandemics, famines, and similar situations, despite that from 
a different standpoint their anti-democratic, anti-liberties approach could lead to a better performance than that of democracies.

On average, authoritarianisms do not tend to be testing: while only four authoritarian regimes managed to massify testing, 14 were outstandingly ineffective with regards to testing (Table 3 ). These 14 countries are located in Southeast Asia — Bangladesh, Myanmar, Thailand_, the Middle East - Iran, Pakistan —, Africa - Ethiopia, Morocco, Rwanda_-, and one of them is in Latin American, Cuba. As in the previous case, there seems to be a direct relationship between testing and level of development, expressed in the fact that these countries are across the board developing, in addition to the association with low levels of democracy.

Table 3

Non-testing authoritarianisms

Country

Bangladesh

Cuba

Ethiopia

Iran

Morocco

Myanmar

Pakistan

Philippines

Rwanda

Thailand

Uganda

Ukraine

Vietnam

Zimbabwe 


\subsection{Non-Testing Anocracies}

Anocracies, this is, regimes that are neither fully democratic nor fully autocratic, are typically ineffective in the massification of testing: $76 \%$ of the anocracies under analysis were non-testing. The literature on political regimes and the management of catastrophes does not have a clear expectation for anocracies. However, in principle, given that they are neither democracies nor authoritarianisms, a medium-scale, average response could be expected. Nevertheless, looking at the data, their outlook is quite grim: testing is, on average, worse than in authoritarianisms. Substantively, while both democracies and authoritarianisms are able to produce incentives to massify testing as a disease prevention strategy, anocracies seem almost consistently incapable of producing such incentives. Seemingly, while some authoritarianisms test massively because they have commodity-derived resources and are induced to oversee political stability, and while many democracies test massively due to the accountability link they have with their citizens, anocracies fail in testing massively because they lack the former and the latter.

Non-testing anocracies are in Latin America -El Salvador, Paraguay, Peru, Panama, Mexico-, Southeast and East Asia - Taiwan, Nepal, Malaysia, Indonesia-, all across Africa South Africa, Tunisia Senegal, Nigeria, Kenya, Ghana —, East Europe — Hungary, Croatia, Bulgaria. These incomplete democracies or weak authoritarianisms are located solely in the developing world. In this sense, non-testing anocracies are similar to non-testing authoritarianisms in their level of testing and level of development, with the difference that in anocracies the regime is not fully authoritarian, but governments seem equally unresponsive to the pandemic. 
Table 4

Non-testing anocracies

Country

Argentina

Bulgaria

Bolivia

Brazil

Colombia

Ecuador

Ghana

Croatia

Hungary

Indonesia

Kenya

Mexico

Malaysia

Nigeria

Nepal

Panama

Peru

Paraguay

Senegal

El Salvador

Tunisia

Taiwan

South Africa 


\subsection{Non-Testing Democracies}

Non-testing democracies, democratic regimes in which governments do not massify testing, run against the predictions of the literature in a similar fashion to testing authoritarianisms the former should massify testing and do not, the latter should not massify testing and do. Thinking conjointly on these two sets, a couple of reflections come to mind. On the one hand, democratic accountability is not sufficient to have testing, which expresses in the fact that democracies do not always massify testing, creating the set of non-testing democracies. On the other hand, testing can happen in authoritarian regimes, which implies that democracy is not a necessary condition for testing.

The low number of non-testing democracies signalizes the low correlation between dem-

ocratic regimes and non-testing. From the 85 countries considered in the sample, which include a total number of 26 democracies, only seven are non-testing democracies: Costa Rica, France, Greece, Japan, South Korea, the Netherlands, and Uruguay. Interestingly, the alternative hypotheses of level of development and government effectiveness do not seem explanatory in this case, particularly considering the presence of highly developed countries such as France, Japan, South Korea, and the Netherlands, but also to some extent Costa Rica, Greece, and Uruguay. Another possibility for their low level of testing, despite the fact of being democratic regimes, could be a low level of risk, but this is not necessarily the case, considering their proximity to some of the epicenters of the pandemic: Japan and South Korea to China; France and Greece to Italy (and France to Spain); and Uruguay to Brazil. 
Table 5

Non-testing democracies

Country

Costa Rica

France

Greece

Japan

South Korea

Netherland

Uruguay

In sum, the current stance of the literature on the relationship between regime type and catastrophe management does not fully explain the patterns displayed by PCR SARS-CoV-2 testing. While the literature expects that the more democratic a country is, the more effective the country will be at facing the pandemic, testing data shows that the relationship is curvilinear: both authoritarianisms and democracies are able to massify testing - although democracies tend to do it more-, while anocracies struggle to do so. In this sense, there are not only testing democracies and non-testing authoritarianisms as the literature would suggest, but also testing authoritarianisms - a limited number, but nevertheless existent-, non-testing democracies, and anocracies that are usually non-testing.

That said, political factors cannot be expected to account for the entire variance in testing. Presumably, structural factors such as level of development and the institutional capacity of the state are highly likely to have a role. Additionally, strictly speaking pandemic factors could have an effect, for example the date in which the first COVID-19 case was registered. The following section explores the possible influence of this alternative, though not mutually exclusive, hypotheses. 


\section{$5 \quad$ Alternative Hypotheses}

Besides political features, several other aspects can be hypothesized to impact SARS-CoV-2 testing. To begin with, more affluent countries can be believed to test more widely than poor countries, especially considering the high price of each test (+/- \$150 USD) and that the massification of testing implies multiplying this price for hundreds of thousands or even millions. In fact, this is the case: there is a strong linear relationship between GDP per capita and COVID-19 tests (Figure 1). Among the typical cases - this is, those that are closer to the regression line - with high development and an important massification of testing are Singapore, Ireland, and Germany. There are also two countries that outstandingly outperform in testing with respect to their level of development, Bahrain and Iceland: their GDP per capita is of around $\$ 40,000$ — which is comparatively not particularly high — and have performed around 180 tests per 1,000 people. In counterpart, Qatar with a GDP of $\$ 140,000$, has only massified testing to a certain extent, with around 70 tests per one thousand people. 
Figure 2

\section{GDP per capita (US dollars) and SARS-CoV-2 tests}

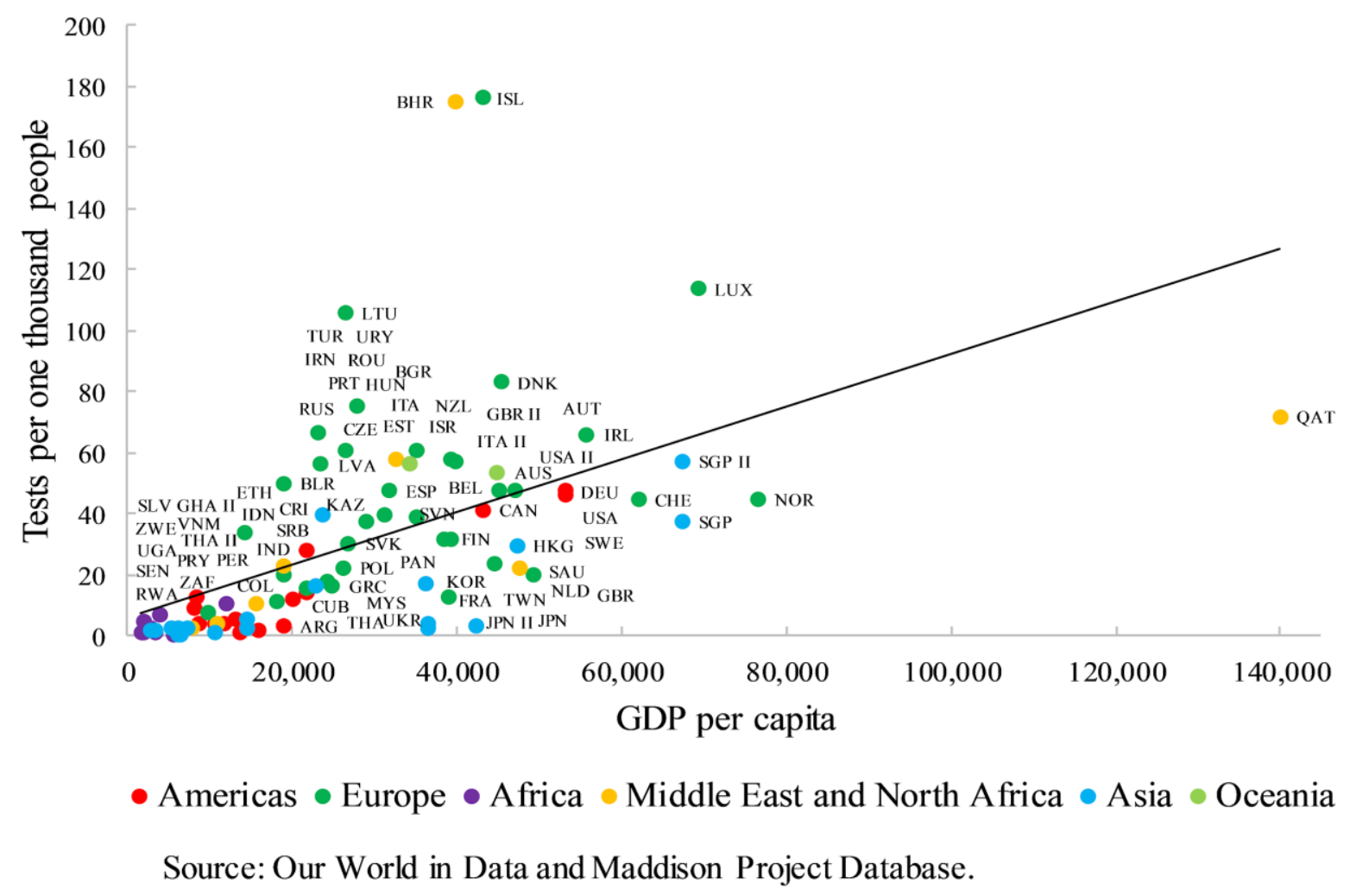

Another alternative hypothesis is government effectiveness: since performing SARS-CoV-2 testing relies especially or exclusively on the hands of governments, more effective governments should perform more tests. In fact, there is a relationship between governmental effectiveness and tests, but not as linear as believed (Figure 3). The relationship is exponential, which expresses graphically in a curve that is basically flat in the beginning and progressively increases the slope while the value in $\mathrm{X}$ increases. Substantively, this means that testing does not generally increase while government effectiveness increases, but that this happens only when effectiveness is high — the case of Iceland, Luxembourg, Denmark, Germany, and the U.S. The most clear exception to this "rule" is Bahrain, which has a mainly ineffective government but that has managed to massify testing. In general, having a low or medium level of state capacity — this is, a not-high level — is basically equally irrelevant for testing, although high effectiveness does not 
guarantee massive testing. In the necessity and sufficiency language, high government effectiveness seems a necessary condition for testing (i.e., no high effectiveness, no massive testing), although not a sufficient one (i.e., some countries have high government effectiveness and low testing, such as the Netherlands, Sweden, Hong Kong, Finland, and Japan).

Figure 3

\section{Government effectiveness and SARS-CoV-2 tests}

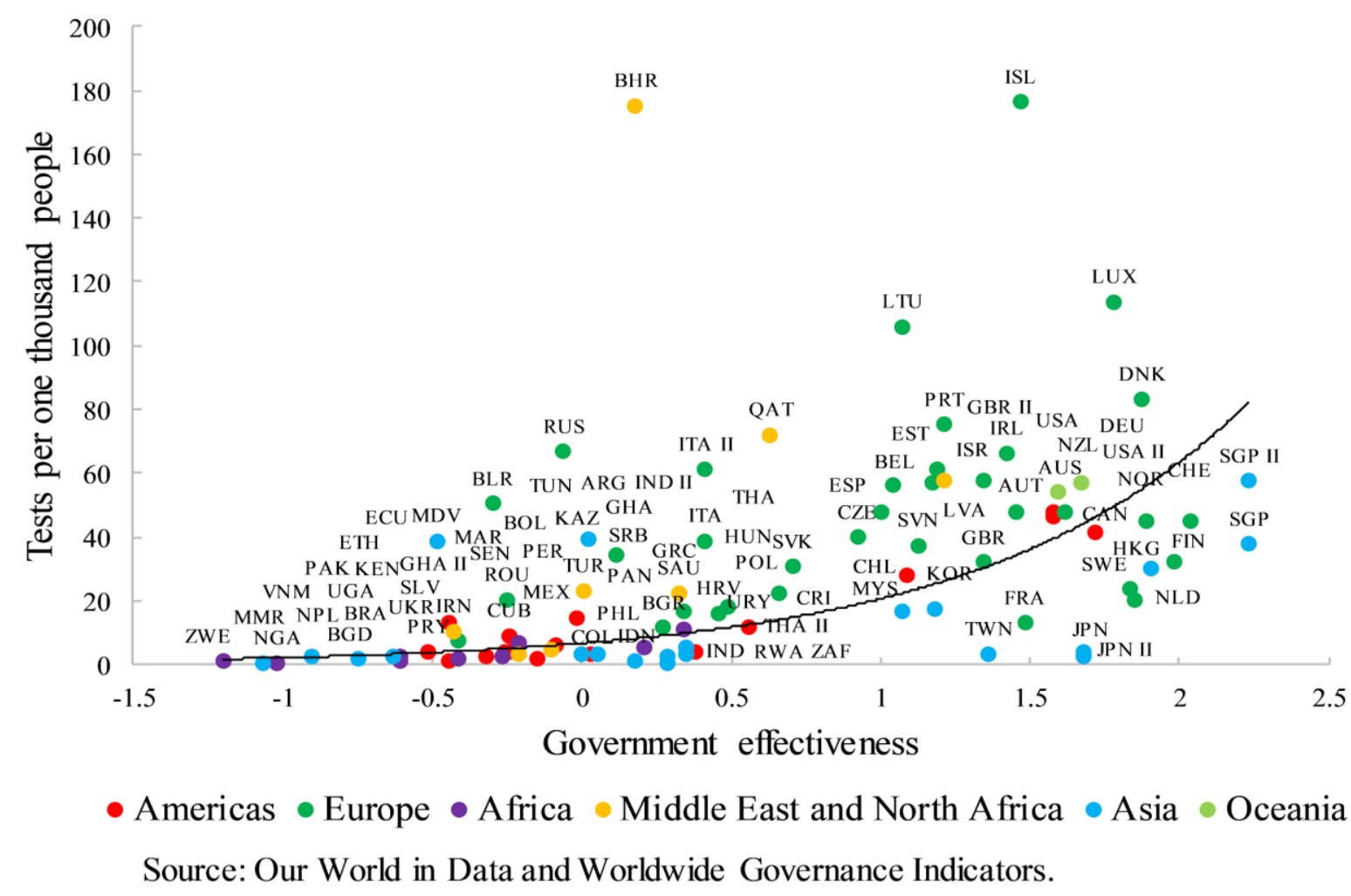

Beyond regime type, development, and institutional capacity, there is a public health feature that can be expected to impact the magnitude of testing: the date in which the first case was detected in a country. One could reasonably expect that the earlier a country had its first case diagnosed, the more tests per 1,000 people that country could and should have performed, since more time has elapsed. Surprisingly, this is not the case (Figure 4). As a matter of fact, some countries that had their first case recently have been able to run more tests than the COVID-19 pioneering countries. The most extreme cases are, on one end, those that had their first case in January and have only performed less than 20 tests per 1,000 people - Thailand, Japan, Korea, 
Taiwan, France - and, on the opposite end, those that had their first case in late February or early March and have ran over 80 tests per 1,000 people - Iceland, Bahrain, Luxemburg, Lithuania, and Denmark.

Figure 4

\section{First case day and SARS-CoV-2 tests}

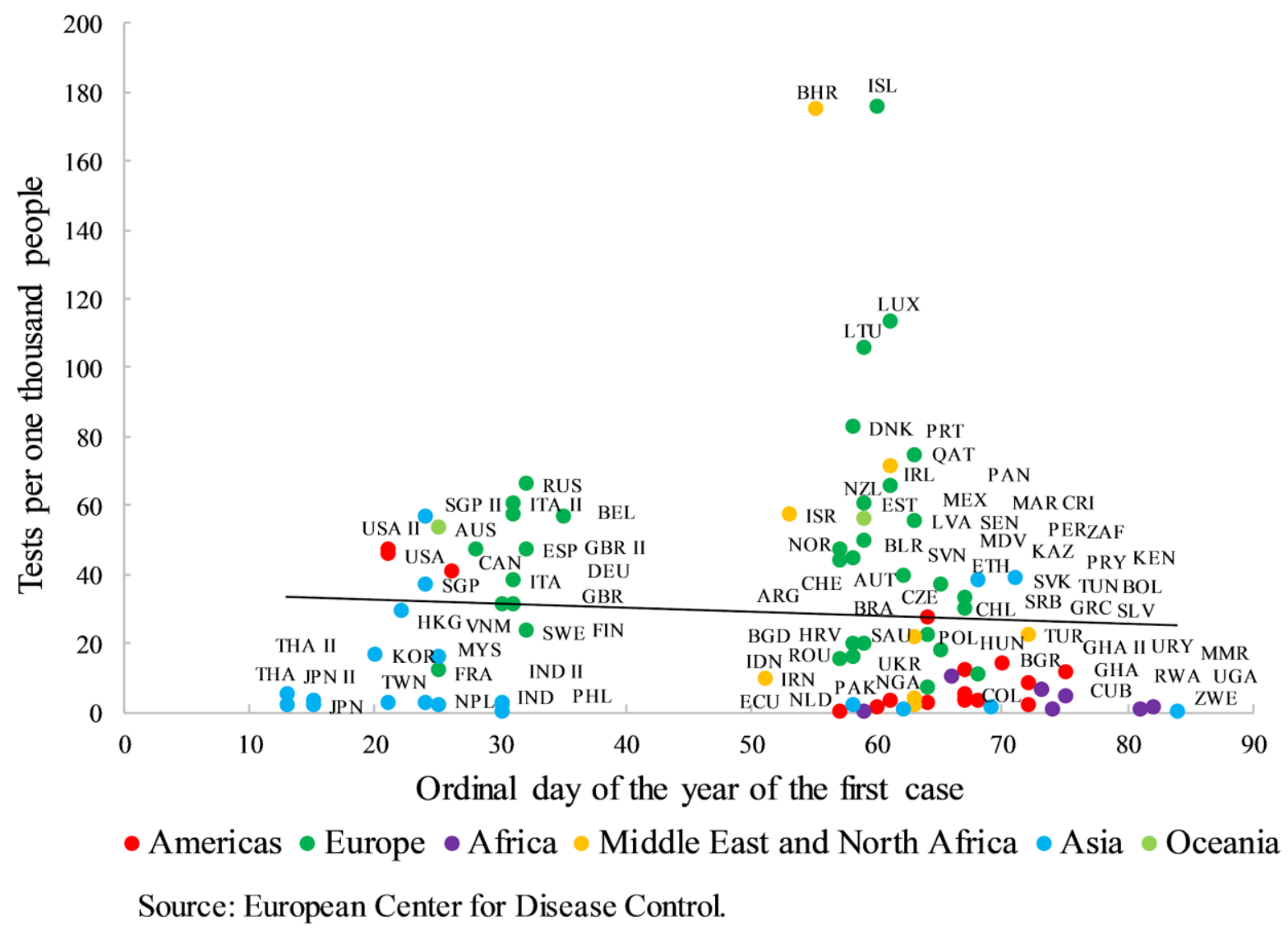

Per the analyses introduced above, economic and institutional structures have a clear effect in the massification of SARS-CoV-2 testing. However, their impact is different. While development has a linear effect (i.e., more development, more testing), governmental effectiveness has an exponential effect (i.e., only when there is a high level of effectiveness, more effectiveness, more testing).

A surprising finding in this regard is the null effect of a strictly speaking pandemic factor on testing, such as the date in which the epidemic began in a given country. Having more days with the epidemic, and therefore having had more time to prepare infrastructure and equipment for 
testing and to actually run the tests, is unrelated to the number of tests performed. In this sense, and counterintuitively, health factors have much less to do with the testing strategy, than political, economic, and institutional factors.

\section{Conclusion}

The question about the effectiveness of different political regimes to face catastrophic situations — famines, natural disasters, pandemics, etc. - has been visited several times. The literature has converged in the quite optimistic view that the deepening of democratic accountability creates incentives for governments to respond better to famines - the most revised type of catastropheand, by extension, other similar situations.

Evaluating such proposition using evidence from the ongoing COVID-19 pandemic and approximating governmental response with SARS-CoV-2 testing - a crucial strategy to contain the pandemic, which is mainly in hands of the governments, and that can be compared from country to country - this does not seem the case. In fact, there are not only testing democracies and nontesting authoritarianisms, as the literature would expect, but also non-testing democracies and testing authoritarianisms, besides anocracies, which have been basically incapable of massifying testing.

The results have implications for our understanding of democracies and authoritarianisms when faced with the need of preventing the expansion of a global pandemic as the one the world is undergoing. First, democratic accountability is not enough to have a government that makes efforts to prevent the expansion of a pandemic. Although the chances of having testing strategies are larger than in authoritarianisms - which can be seen in the fact that there are many more testing democracies than testing authoritarianism, even controlling by the absolute number of both-, democracies are not necessarily successful in the massification of testing, as can be seen in the case of non-testing democracies.

Second, authoritarianisms may create conditions for SARS-CoV-2 testing and effective pandemic management. However, this has happened exclusively in rentier states, where the public 
sector has plenty of resources available, derived from natural resources — especially oil - and that can be used for testing. Additionally, the political leadership has strong incentives to hinder any kind of political and social unrest that might arise as a consequence of the epidemic and therefore launches ambitious testing campaigns. Therefore, not any authoritarianism can be expected to be able to massify testing, but only those with this very specific feature. In contrast, in the case of anocracies there is a strong association with low levels of testing. In brief, while democracies and authoritarianisms have massified testing under certain conditions, anocracies basically have not, regardless of the context.

Third, besides the cited political factors, structural elements also play a large role in the massification of testing. On the one hand, the more developed a country is, the more tests performed on average. This seems reasonable once considering the price of testing, with each test having a price of around $\$ 150$ USD. On the other hand, a true massification of testing only seems reachable for those countries with strong, effective states, this is, with the institutional capacity to implement under pressure such a large-scale, long-lasting strategy. In this regard, there seems to be a very limited space for mere political willingness in order for a country to implement massive testing, due to these economic and institutional constraints.

One final word on strictly speaking epidemic factors and testing. Surprisingly, and even when it could sound as a contradiction, the epidemic as such has little to do with the testing response a government might undertake to prevent this epidemic from having a disastrous effect: the earlier a country had its first case does not increase the number of tests performed. So, to be more effective with regards to testing in the response to a pandemic it is basically irrelevant since when you have the epidemic. The crucial factors are political, economic, and institutional, in fact quite distant from the pandemic as such — regime type, development, institutional capacity-, which stress the importance of social science approaches to make sense of the pandemic, the responses, and the effects. 


\section{References}

Adhanom, T. (March 11, 2020a). WHO Director-General's opening remarks at the media briefing on COVID-19. World Health Organization. Retrieved from https://www.who.int.

Adhanom, T. (March 13, 2020b). WHO Director-General's opening remarks at the media briefing on COVID-19 - 13 March 2020. Retrieved from https://www.who.int.

Adhanom, T. (March 16, 2020c). WHO Director-General's opening remarks at the media briefing on COVID-19. World Health Organization. Retrieved from https://www.who.int.

Adhanom, T. (April 13, 2020d). WHO Director-General's opening remarks at the media briefing on COVID-19. World Health Organization. Retrieved from https://www.who.int.

Arons, M. et al. (2020). Presymptomatic SARS-CoV-2 Infections and Transmission in a Skilled Nursing Facility. The New England Journal of Medicine. Published online.

Blaikie, P. et al. (2014). At Risk: Natural Hazards, People's Vulnerability and Disasters. 2nd edition. New York: Routledge.

Burchi, F. (2011). Democracy, Institutions and Famines in Developing and Emerging Countries. Canadian Journal of Development Studies/Revue canadienne d'études du développement, 32(1), $17-31$.

Frey, C., Chen, C. \& Presidente, G. (2020). Democracy, Culture, and Contagion: Political Regimes and Countries Responsiveness to Covid-19. Oxford Martin School. Published online. Retrieved from https://www.oxfordmartin.ox.ac.uk/downloads/academic/Democracy-Culture-andContagion_May13.pdf

Center for Disease Control and Prevention. (2020a). Contact Tracing - CDC's Role and Approach. Retrieved from https://www.cdc.gov.

Centers for Disease Control and Prevention. (2020b). Contact Tracing for COVID-19. Retrieved from https://www.cdc.gov. 
Centers for Disease Control and Prevention. (2020c). Coronavirus Disease 2019 (COVID-19). Testing Overview. Retrieved from https://www.cdc.gov.

Centers for Medicare \& Medicaid Services. (May 19, 2020). Medicare Administrative Contractor (MAC) COVID-19 Test Pricing. Retrieved from www.cms.gov.

Cepaluni, G., Dorsch, M. \& Branyiczki, R. (2020). Political Regimes and Deaths in the Early Stages of the COVID-19 Pandemic. SSRN. Published online. Retrieved from https://papers.ssrn.com/sol3/papers.cfm?abstract_id $=3586767$

Cheibub, J., Hong, J., Przeworski, A. (2020). Rights and Deaths: Government Reactions to the

$\begin{array}{llll}\text { Pandemic. } & \text { Published } & \text { Retrineved }\end{array}$ https://docs.google.com/viewer?a=v\&pid=sites\&srcid=bnl1LmVkdXxhZGFt-

LXByemV3b3Jza218Z3g6MjVjYmNjN2VjNzljZTM2MQ

Collins, Francis. (April 23, 2020). The Challenge of Tracking COVID-19's Stealthy Spread. National Institutes of Health Director's Blog. Retrieved from https://directorsblog.nih.gov.

De Waal, A. (1990). A Re-Assessment of Entitlement Theory in the Light of the Recent Famines in Africa. Development and Change, 21(3), 469-490.

De Waal, A. (1989). Famine that Kills: Darfur, Sudan. New York: Oxford University Press.

Drèze, J., \& Sen, A. (eds.). (1990). The Political Economy of Hunger. New York: Oxford University Press.

Drèze, J. \& Sen, A. (1989). Hunger and Public Action. New York: Oxford University Press.

European Centre for Disease Prevention and Control. (July 1, 2020). Distribution for COVID19 cases worldwide. Retrieved from www.ecdc.europa.eu.

Hahn, S., Shuren, J. (May 9, 2020). FDA Authorizes First Antigen Test to Help in the Rapid Detection of the Virus that Causes COVID-19 in Patients. Food and Drug Administration. Retrieved from https://www.fda.gov. 
Hellewell, J., Abbott, S., Gimma, A., Bosse, N.I., Jarvis, C.I., Russell, T.W., Munday, J.D., Kucharski, A.J., Edmunds, W.J. (2020). Feasibility of controlling COVID-19 outbreaks by isolation of cases and contacts. Lancet Global Health. Published online February 28. https://doi.org/10.1016/S2214-109X(20)30074-7.

Gandhi, M., Yokoe, D.S., Havlir, D.V. (2020). Asymptomatic Transmission, the Achilles's Heel of Current Strategies to Control Covid-19. The New England Journal of Medicine. Published online.

Hellewell, J., Abbott, S., Gimma, A., Bosse, N., Jarvis, C., Russell, T., Munday, J., Kucharski, A., Edmunds, W. (2020). Feasibility of controlling COVID-19 outbreaks by isolation of cases and contacts. Lancet Global Health. Published online.

John Hopkins University. (2020). The Facts About COVID-19 Tests. Retrieved from https://coronavirus.jhu.edu.

Kavanagh, M., \& Singh, R. (2020). Democracy, Capacity, and Coercion in Pandemic Response —COVID 19 in Comparative Political Perspective. Journal of Health Politics, Policy and Law. Published online.

Kucharski, A., Klepac, P., Conlan, A.., Kissler, S., Tang, M., Fry, H., Gog, J., Edmunds, W. (2020). Effectiveness of isolation, testing, contact tracing, and physical distancing on reducing transmission of SARS-CoV-2 in different settings: a mathematical modelling study. Lancet Infectious Diseases. Published online.

Lee, D. \& Lee, J. (2020). Testing on the move: South Korea's rapid response to the COVID-19 pandemic. Transportation Research Interdisciplinary Perspectives. Published online.

Lin, T. (2015). Governing Natural Disasters: State Capacity, Democracy, and Human Vulnerability, Social Forces, 93(3), 1267-1300.

Ministry of Health of Singapore. (June 15, 2020). Charges for COVID-19 Test and Stay at Dedicated SHN Facility. Retrieved from www.moh.gov.sg. 
Ministry of Health of Iceland. (June 15, 2020). Travellers to be tested at border - Science to guide path to the easing of travel restrictions. Retrieved from www.government.is.

Morawska, L. \& Cao, J. (2020). Airborne transmission of SARS-CoV-2: The world should face the reality. Environmental International. Published online.

National Institutes of Health. (April 29, 2020). NIH mobilizes national innovation initiative for COVID-19 diagnostics. Retrieved from https://www.nih.gov.

New York Times. (January 30,2020). Deaths Surpass 200, and State Department Urges Against Travel to China. Retrieved from www.nytimes.com.

New York Times. (June 30, 2020). How the Coronavirus Pandemic Unfolded: A Timeline. Retrieved from www.nytimes.com.

Platt, R. (2012). Disasters and Democracy: The Politics of Extreme Natural Events. Washington, D.C.: Island Press.

Reuters. (December 31, 2019). Chinese officials investigate cause of pneumonia outbreak in Wuhan. Retrieved from https://www.reuters.com.

Ross, M. (2015). What Have We Learned about the Resource Curse? Annual Review of Political Science, 18, 239-259.

Ross, M. (2013). The Oil Curse: How Petroleum Wealth Shapes the Development of Nations. Princeton: Princeton University Press.

Ross, M. (1999). The Political Economy of the Resource Curse. World Politics, 51(2), 297-322.

Rubin, O. (2011). Democracy and Famine. New York: Routledge.

Rubin, O. (2009). The Merits of Democracy in Famine Protection -Fact or Fallacy? European Journal of Development Research, 21(5), 699-717.

Sen, A. (2020, April 15). A Better Society Can Emerge From The Lockdowns. Financial Times. Retrieved from https://www.ft.com. 
Sen, A. (1999). Development as Freedom. New York: Oxford University Press. . (1982). Poverty And Famines: An Essay On Entitlement And Deprivation. New York: Oxford University Press.

Watts, M. (2013). Silent Violence: Food, Famine, and Peasantry in Northern Nigeria. Athens. Georgia University Press.

Whitman, J.D., Hiatt, J., Mowery, C.T., Shy, B.R., Yu, R. et al. (2020). Test performance evaluation of SARS-CoV-2 serological assays. medRxiv. Retrieved from https://www.medrxiv.org.

Woloshin, S., Patel, N., Kesselheim, A. (June 5, 2020). False Negative Tests for SARS-CoV-2 Infection —Challenges and Implications. New England Journal of Medicine. Published online. Retrieved from https://www.nejm.org.

World Health Organization. (May 10, 2020a). Contact tracing in the context of COVID-19. Interim Guidance. Retrieved from https://www.who.int.

World Health Organization. (2020b). Coronavirus disease 2019 (COVID-19). Situation report 75. Retrieved from https://www.who.int.

World Health Organization. (March 22, 2020c). Critical preparedness, readiness and response actions for COVID-19. Interim guidance. Retrieved from https://www.who.int.

World Health Organization. (March 20, 2020d). Global surveillance for COVID-19 caused by human infection with COVID-19 virus. Interim guidance. Retrieved from https://www.who.int.

World Health Organization. (2020e). Naming the coronavirus disease (COVID-19) and the virus that causes it. Retrieved from https://www.who.com.

World Health Organization. (February 28, 2020f). Report of the WHO-China Joint Mission on Coronavirus Disease 2019 (COVID-10). Report. Retrieved from https://www.who.int. 
World Health Organization. (January 23, 2020g). Statement on the meeting of the International Health Regulations (2005) Emergency Committee regarding the outbreak of novel coronavirus (2019-nCoV). Retrieved from https://www.who.int.

World Health Organization. (January 30, 2020h). Statement on the second meeting of the International Health Regulations (2005) Emergency Committee regarding the outbreak of novel coronavirus (2019-nCoV). Retrieved from https://www.who.int.

World Health Organization. (May 10, 2020i). Surveillance strategies for COVID-19 human infection. Interim guidance. Retrieved from https://www.who.int.

Zuo, M., Cheng, L., Yan, A \& Yau, C. (December 31, 2020). Hong Kong takes emergency measures as mystery 'pneumonia' infects dozens in China's Wuhan city. South China Morning Post. Retrieved from https://www.scmp.com. 


\section{Appendix}

Electoral democracy and SARS-CoV-2 tests

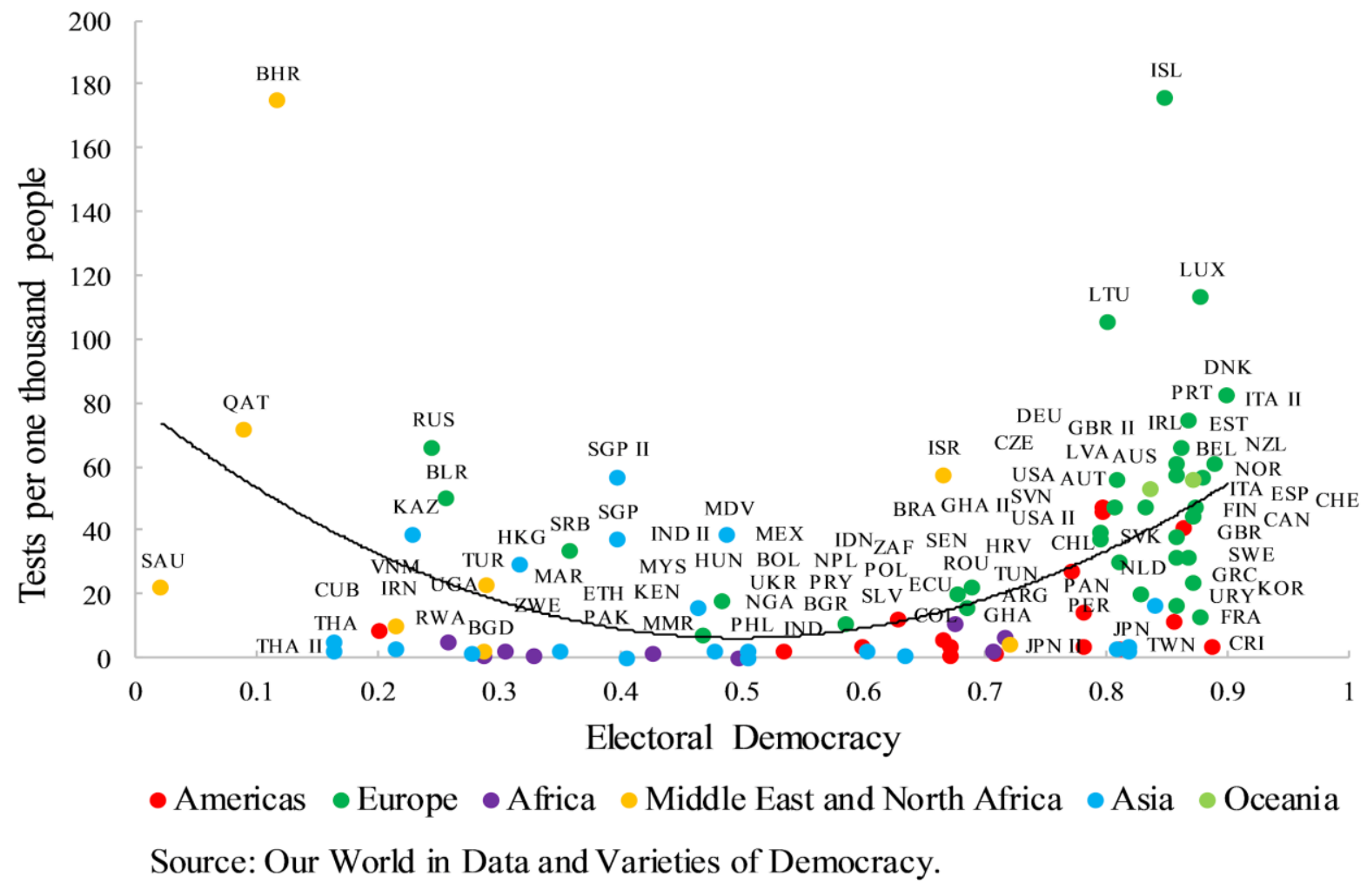

